\title{
STRATEGI BERSAING PADA GELATIK RESIDENCE PALU
}

\author{
TANWIR DG. DJUMA \\ JOHNNY TANAMAL \\ SYAMSUL BAHRI DP \\ Jurusan Manajemen, Fakultas Ekonomi, Universitas Tadulako \\ Email: tanwirdjuma94@gmail.com
}

\begin{abstract}
PT. Regional Trypillian is a company that is engaged in the development of new houses to prosper the society, especially by providing residence and develop its role in economic development in marketing the residential products and utilization of manpower. The establishment of the company initiated by Mr. Sofyan Hudri since February 15, 2014, starting from an attempt to manage, market, and produce home with investors/landowners. Wren's housing residence consists of 2 types: type 50 and type 90. The purpose of this study is to determine competition faced by Wren Residence in Palu and to examine alternative strategies that can be used by Wren Residence. Data analysis technique used is the SWOT analysis (Strength, Weakness, Opportunity, Threat). Based on the results of SWOT analysis in the form of matrix diagram and IE table, it finds that competitive strategies of Wren Residence is focused on aggressive strategy (growth-oriented strategy) that is suitable with the existing opportunities.
\end{abstract}

Keywords: residence, SWOT analysis, strategy

\begin{abstract}
ABSTRAK
PT. Regional Trypillian adalah perusahaan yang bergerak dalam pengembangan rumah baru untuk mencapai kesejahteraan masyarakat, terutama dengan menyediakan tempat tinggal dan mengembangkan perannya dalam pembangunan ekonomi dalam memasarkan produk hunian dan pemanfaatan tenaga kerja. Pembentukan perusahaan yang diprakarsai oleh Bapak Sofyan Hudri sejak 15 Februari 2014 ini, mulai dari usaha mengelola, memasarkan, dan menghasilkan rumah dengan investor / pemilik lahan. Tempat tinggal Wren terdiri dari 2 tipe: tipe 50 dan tipe 90. Tujuan dari penelitian ini adalah untuk mengetahui kompetisi yang dihadapi Wren Residence di Palu dan untuk mengkaji strategi alternatif yang dapat digunakan oleh Wren Residence. Teknik analisis data yang digunakan adalah analisis SWOT (Strength, Weakness, Opportunity, Threat). Berdasarkan hasil analisis SWOT berupa diagram matriks dan tabel IE, maka strategi kompetitif Wren Residence difokuskan pada strategi agresif (strategi berorientasi pertumbuhan) yang sesuai dengan peluang yang ada.
\end{abstract}

Kata Kunci: perumahan, analisa SWOT, dan strategi

\section{PENDAHULUAN}

\section{Latar Belakang Penelitian}

Rumah bukan hanya sebuah bangunan struktural, melainkan juga tempat kediaman yang memenuhi syarat-syarat kehidupan yang layak, dipandang dari berbagai segi kehidupan masyarakat. Rumah dapat dimengerti sebagai tempat perlindungan, untuk menikmati kehidupan, beristirahat dan bersuka ria bersama keluarga. Di dalam rumah, penghuni memperoleh kesan pertama dari kehidupannya. Rumah harus menjamin kepentingan keluarga, yaitu untuk tumbuh, memberi kemungkinan untuk hidup bergaul dengan tetangganya, dan lebih dari itu, rumah harus memberi ketenangan, kesenangan, kebahagiaan, dan kenyamanan pada segala peristiwa hidupnya.

Rumah merupakan sebuah bangunan, tempat manusia tinggal dan melangsungkan kehidupannya. Disamping itu rumah juga merupakan tempat berlangsungnya proses sosialisasi pada saat seorang diperkenalkan kepada norma dan adat kebiasaan yang berlaku di dalam suatu masyarakat. Jadi setiap perumahan memiliki sistem nilai yang berlaku bagi warganya. Sistem nilai tersebut berbeda antara satu perumahan dengan perumahan yang lain, tergantung pada daerah ataupun keadaan masyarakat setempat.

Pertumbuhan penduduk yang relatif tinggi khususnya diperkotaan sangat memengaruhi kebutuhan perumahan di berbagai kota di Indonesia. Kondisi ini tentunya dimanfaatkan oleh perusahaan dengan 
menyediakan berbagai jenis perumahan di Kota Palu sebagaimana dengan di kotakota lainnya di Indonesia juga meningkat dengan pesat. Ada beberapa developer perumahan telah membangun kompleks perumahan antara lain perumahan Grand Tagari Permai, Perumahan Palupi Permai, Perumahan Bumi Roviga, perumahan Citra Banua Nagaya, Perumahan Delta Asri Kabonena, Permata Regence, Merpati Residence, Permata Khatulistiwa dan lain-lain. Dari sekian banyak perumahan yang disebutkan diatas yang menarik untuk diteliti adalah perumahan Gelatik Residence yang bertempat di jalan Gelatik. Jenis perumahan ini yaitu tidak ready stock tetapi harga yang ditawarkan pun cukup relatif terjangkau sesuai dengan tingkatan pendapat masyarakat menengah keatas, selain itu lokasinya pun cukup stategis karena dekat dengan bandara dan berada dalam pusat kota Palu. Perumahan Gelatik residence ini terdari 2 tipe yaitu type 50 dan tipe 90 . Model desain perumahan ini berbeda dengan perumahan pada umumnya karena bentuk bangunannya sudah tergolong moderen.

Tabel 1. Harga Perumahan Gelatik Residence

\begin{tabular}{cccc}
\hline No & Type & Harga Jual & Uang Muka \\
\hline 1 & Type 50 & Rp. 495.000.000 & $30 \%$ \\
2 & Type 90 & Rp. 695.000.000 & $30 \%$ \\
\hline
\end{tabular}

Sumber : PT. Trypillian Regional, 2016

Berdasarkan tabel di atas, harga yang ditawarkan pengembangan relatif terjangkau untuk mereka yang berpendapatan menenah keatas. Alasan mempertimbangkan faktor harga karena hal tersebut berkaitan dengan pendapatan mereka. Bagi mereka yang berpendapatan besar maka harga tidak akan menjadi masalah, tetapi mereka lebih mempertimbangkan faktor lokasi dan kualitas produk dalam hal ini faktor bangunan. Persaingan yang semakin ketat dalam industri perumahan menuntut perumahan Gelatik Residence untuk menerapkan strategi pemasaran yang tepat agar mampu memenangkan persaingan di dalam kota Palu.

Melakukan strategi pemasaran yang baik kepada masyarakat adalah salah satu kegiatankegiatan pokok yang selamanya dilakukan oleh para pengusaha yang dalam usahanya untuk dapat mempertahankan kegiatan produksinya tersebut. Strategi pemasaran tersebut dilakukan untuk mempertahankan kelangsungan usahanya untuk berkembang dan mendapatkan laba. Berhasil atau tidaknya pengusaha perumahan bergantung bagaimana cara pelaku usaha tersebut dalam mengelola suatu usahanya dengan cara menggunakan fungsi-fungsi yang telah ada pada sistem pemasaran.

Hal ini dapat dilakukan, jika pelaku usaha dapat mempertahankan dan meningkatkan penjualan produk yang mereka produksi. Dengan melakukan penarapan strategi pemasaran yang akurat melalui pemanfaatan peluang bisnis, diharapkan posisi atau kedudukan sebuah usaha dapat ditingkatkan atau dipertahankan.

Salah satu perumusan strategi perusahaan dapat dilakukan dengan menggunakan analisis SWOT, dikarenakan dalam analisis SWOT terdapat empat unsur yang menjadi penentu dalam pengambilan keputusan yang strategis. SWOT terdiri dari Strengh (kekuatan), Weakness (kelemahan), Opportunities (peluang) dan Treath (ancaman), yang mana semua itu sangat diperlukan dalam membangun sebuah usaha.

Rangkuti (2014) mengemukakan bahwa analisis SWOT merupakan analisis identifikasi berbagai faktor secara sistematis untuk merumuskan strategi perusahaan. Proses pengambilan keputusan strategis selalu berkaitan dengan pengembangan misi, tujuan, strategi, dan kebijakan perusahaan.

Strategi pemasaran yang maju dan berkembang senantiasa memperhatikan adanya unsur menarik perhatian segmen pasar atau pangsa pasar dalam kegiatan pemasaran. Dengan permasalahan yang tersebut maka menggunakan analisis SWOT untuk membantu dalam menentukan strategi apa yang tepat khususnya strategi pemasaran sehingga nantinya diharapkan perusahaan akan memperoleh keuntungan yang maksimal.

Berdasarkan latar belakang masalah yang telah dikemukakan, maka permasalahan penelitian adalah bagaimana strategi bersaing yang digunakan oleh Perumahan Gelatik Residence sehingga dapat unggul dalam bisnis pangsa pasar di Kota Palu, dengan tujuan untuk mengetahui dan menganalisis strategi bersaing apa yang paling tepat dalam meningkatkan penjualan pada Perumahan Gelatik Residence. 


\section{KAJIAN LITERATUR DAN PENGEMBANGAN HIPOTESIS \\ Pengertian Pemasaran}

Didefinisikan secara luas, pemasaran adalah proses sosial dan manajerial di mana pribadi atau organisasi memperoleh apa yang mereka butuhkan dan inginkan melalui penciptaan dan pertukaran nilai dengan yang lain. Dalam konteks bisnis yang lebih sempit, pemasaran mencakup menciptakan hubungan pertukaran muatan nilai dengan pelanggan yang menguntungkan. Karena itu, kita mendefinisikan pemasaran (marketing) sebagai proses di mana perusahaan menciptakan nilai bagi pelanggan dan menciptakan nilai yang kuat dengan pelanggan, dengan tujuan menangkap nilai dari pelanggan sebagai imbalannya (Kotler \& Amstrong 2008).

\section{Keunggulan Bersaing}

Keunggulan bersaing disebabkan oleh pilihan strategi yang dilakukan perusahaan untuk merebut peluang pasar Porter (2007) keunggulan bersaing merupakan hasil dari kemampuan perusahaan menanggulangi kelima faktor persaingan secara lebih baik ketimbang para pesaingnya.

\section{Analisis SWOT}

Analisis SWOT tidak hanya menarik untuk dikaji oleh para manajer atau para top management perusahaan, namun menjadi menarik juga dikaji secara pribadi. Terutama untuk melihat potensi diri seseorang serta prospek yang akan diraih dalam pekerjaannya di masa depan. Ini sebagaimana dikatakan oleh Stephen P. Robbins dan Mary Coulter (di kutip dalam buku Fahmi, 2014) bahwa, "sebuah analisis SWOT dapat merupakan alat yang bermanfaat untuk memeriksa keterampilan, kemampuan, pilihan karir, dan peluang-peluang karir anda sendiri".

Jika dahulu SWOT sering dijadikan sebagai salah satu konsep dalam memenangkan pertempuran sebagaimana yang di kemukakan oleh Sun Tzu ( dikutip dalam buku Fahmi, 2014) "apabila kita telah mengenal kekuatan dan kelemahan lawan sudah dapat dipastikan bahwa kita akan dapat memenangkan pertempuran"

Maksud dari pengertian yang dituliskan diatas adalah dimana dulunya analisis SWOT ini hanya sering digunakan untuk memenangkan sebuah pertempuran, tetapi sekarang analisis SWOT juga digunakan dalam menentukan strategi sebuah perusahaan atau usaha agar dapat berjalan dengan baik meskipun banyak saingan.

\section{METODE PENELITIAN}

\section{Metode Pengumpulan Data}

Data yang digunakan dalam penelitian ini diperoleh dengan menggunakan beberapa metode pengumpulan data, yaitu penelitian Lapangan ( Field Research) yaitu penelitian yang dilakukan pada usaha bersangkutan untuk memperoleh data yang berhubungan dengan penulisan dengan cara :

1. Observasi, yaitu pengamatan secara langsung terhadap pihak perumahan Gelatik Residence, cara ini dapat memberikan informasi yang lebih akurat berdasarkan kenyataan yang ada.

2. Wawancara, yaitu peneliti melakukan serangkaian tanya jawab secara langsung salah satu karyawan bagian pemasaran mengenai kondisi internal dan eksternal perusahaan yang berhubungan dengan strategi pemasaran yang diterapkan.

\section{Operasional Variabel}

Variabel penelitian ini terdiri dari dua bagian yaitu faktor internal dan faktor eksternal., yang masing-masing bagian terdiri dari dua sub bagian. Faktor iksternal terdiri dari kekuatan dan kelemahan, sedangkan faktor eksternal terdiri dari dari peluang dan ancaman.

\section{Metode Analisis}

Metode analisis data yang digunakan adalah metode adalah sebagai berikut:

1. Analisis Kuantitatif Deskriptif

Analisis kuantitatif deskriptif adalah menganalisis dengan menjelaskan dari perhitungan hasil kuisioner yeng telah disebarkan dan diisi oleh responden. Dan kemudian dilanjutkan dengan analisis kuantitatif yang menggunakan analisis IFAS dan EFAS.

2. Analisis Kualitatif

Analisis kualitatif yaitu serangkaian kegiatan menganalisis data dalam obyek penelitian yang tidak dinyatakan dengan angka-angka 
Menurut Rangkuti (2014), penelitian menunjukan bahwa kinerja perusahaan dapat ditentukan oleh kombinasi factor internal dan eksternal. Kedua factor tersebut harus dipertimbangkan dalam analisis SWOT. Matriks kekuatan, kelemahan, peluang dan ancaman adalah sebuah alat pencocokan yang penting yang membantu para manajer mengembangkan empat jenis strategi: Strategi SO (kekuatanpeluang), Strategi WO (kelemahan-peluang), Strategi ST (kekuatan-ancaman), dan Strategi WT (kelemahan- ancaman). Mencocokkan faktor-faktor eksternal utama merupakan bagian tersulit dalam mengembangkan Matriks SWOT dan membutuhkan penilaian yang baik dan tidak ada satu pun paduan yang paling benar.

\section{HASIL DAN PEMBAHASAN Analisis Lingkungan Eksternal}

Umumnya perusahaan memonitor setiap unit usaha dan harus mengkategorikan keuntungan, menyiapkan strategi pemasaran untuk mengikuti atau kecenderungan dan perkembangan lingkungan yang penting. Dari setiap kecenderungan atau perkembangan, kemudian pemasar mengidentifikasi peluang dan ancaman yang ada. Salah salah satu tujuan yang utama memonitor lingkungan adalah untuk mengidentifikasi peluang-peluang yang baru dan juga ancaman yang timbul karena adanya suatu kecenderungan tidak menguntungkan dalam lingkungan yang akan mengarah pada tindakan pemasaran.

Salah satu tujuan utama memonitor lingkungan adalah untuk mengidentifikasi peluangpeluang baru juga ancaman yang timbul karena adanya suatu kecenderungan yang tidak menguntungkan dalam lingkungan yang akan mengarah pada tindakan pemasaran PT. Trypillian Regional dalam menganalisis lingkungan eksernalnya adalah sebagai berikut :

Perusahaan haruslah dapat memiliki kemampuan yang unggul dalam rangka mencapai dan mempertahankan keuanggulan persaingan. Dibawah ini akan dipaparkan beberapa peluang dan ancaman yang dimiliki oleh perusahaan PT. Trypillian Regional antara lain:

\section{Peluang}

1. Peraturan pemerintah yang mendorong pembangunan perumahan nomor 29/1974 tentang perusahaan pembangunan nasional

2. Kecenderungan masyarakat dalam memilih wilayah yang aman, dan dekat dengan fasilitas umum seperti bandara dan pusat kota

3. Pertumbuhan penduduk yang semakin meningkat maupun jumlah pendatang yang akan membutuhkan tempat tinggal baru

4. Kepercayaan masyarakat terhadap kualitas perumahan Gelatik Residence untuk memberikan layanan terbaik terhadap konsumen.

5. Inovasi baru

\section{Ancaman}

1. Munculnya berbagai perumahan/pesaing baru di kota Palu

2. Gaji buruh yang semakin tinggi yang akan mempengaruhi harga jual perumahan menjadi mahal atau sulit terjangkau

3. Kenaikan harga material bangunan

4. Perkembangan berbagai tipe perumahan dari para pesaing

\section{Analisis Lingkungan Internal}

Setiap unit usaha haruslah mengevaluasi kekuatan dan kelemahan secara periodik, ini dapat dilakukan dengan analisis terhadap kemampuan perusahaan dibidang pemasaran, keuangan, produksi dan organisasi.

\section{Bidang Pemasaran}

Kegiatan dalam pemasaran terhadap beberapa konsep yang mana masing-masing konsep memiliki tujuan yang berbeda. Konsep ini timbul dari suatu periode ke periode lainnya akibat perkembangan pengetahuan baik produsen maupun konsumen. Penggunaan konsep ini tergantung kepada perusahaan yang juga dikaitkan dengan jenis usaha dan tujuan perusahaan yang bersangkutan.

Menurut Kotler \& Keller (2013) ada 4 konsep dalam pemasaran dimana masing-masing konsep saling bersaing satu sama lainnya. Setiap konsep dijadikan landasan oleh masing-masing perusahaan. Adapun konsep yang dimaksud adalah sebagai berikut : 
1. Konsep produksi, yaitu konsep yang menekankan kepada volume produksi yang seluas-luasnya (distribusi) dengan harga serendah mungkin

2. Konsep produk, yaitu konsep yang menekankan kepada kualitas, penampilan dan ciri-ciri terbaik.

3. Konsep penjualan, dalam konsep ini kegiatan pemasaran ditekankan leboh agresif melalui usahausaha promosi

4. Konsep pemasaran, yaitu konsep yang bersifat kemasyarakatan. Konsep ini menekankan kepada penentuan kebutuhan, keinginan dan minat pasar serta memberikan kepuasan sehingga memberikan kesejahteraan konsumen dan masyarakat.

Perkembangan pemasaran dunia usaha dewasa ini tidak terlepas dari aktifitas yang dilaksanakan. Dimana dalam aktifitas ini terjadi suatu hambatan seperti adanya perubahan dalam lingkungan pemasaran, sehingga perusahaan ditantang untuk selalu mengevaluasi posisi kekuatan dan kelemahan perusahaan.

\section{Aspek produk atau bangunan}

Pengertian produk adalah suatu yang dapat memenuhi kebutuhan dan keinginan pelanggan. Sedangkan pengertian produk menurut Kotler adalah suatu yang dapat ditawarkan kepasar untuk mendapatkan perhatian untuk dibeli, untuk digunakan atau dikonsumsi yang dapat memenuhi kinginan dan kebutuhan konsumen.

Perusahaan PT. Trypillian Regional adalah perusahaan yang bergerak dibidang developer yang menyediakan perumahan dengan tipe 50 dan tipe 90 . Oleh karena itu perusahaan tersebut sangat memperhatikan hal-hal yang berhubungan dengan bangunan antara lain :

1. Jenis rumah yang dibangun sesuai dengan selera pasar, dalam arti disesuaikan dengan kecenderungan keinginan masyarakat.

2. Kualitas bangunan yang dihasilkan dapat diandalkan. Dalam arti ketika membuat bangunan, pihak pengembang mampu mempertanggung jawabkan kualitas bangunannya, sebab selama ini perumahan mempunyai image yang kurang baik dimasyarakat. Sehingga pihak pengembang usaha untuk memberikan kesan bahwa bangunan yang ditawarkan memiliki kualitas yang tinggi.

3. Ukuran bangunan yang dibuat sesuai dengan ukuran konvensonal yaitu dengan type 50 dan type 90 .

\section{Aspek harga}

Penentuan harga menjadi sangat penting untuk diperhatikan, mengingat harga sangat mementukan laku tidaknya produk atau bangunan yang dibuat. Kesalahan dalam menentukan harga akan berakibat terhadap bangunan yang ditawarkan. Penetuan harga oleh perusahaan PT. Trypillian Regional dimaksudkan dengan berbagai tujuan yang hendak dicapai oleh perusahaan antara lain:

1. Untuk dapat bertahan dalam persaingan. Perusahaan menetapkan haraga bersaing dengan pengembang lainnya, namun tetap menyesuaikan dengan total anggaran bangunan selama proses pembuatan sampai dengan selesai.

2. Karena pesaing. Dalam hai ini penentuan harga dengan melihat harga pesaing dengan tujuan agar harga yang ditawarkan jangan melebihi harga pesaing baik produkyang dihasilkan maupun dalam pembelian bahan baku.

\section{Bidang Keuangan}

Bidang keuangan ini melihat bagaimana profitabilitas (kemampuan manghasilkan) perusahaan yang dinilai dalam satu periode waktu dan dinilai dari stabilitas keungan perusahaan dalamkegiatan operasionalnya.

1. Profitabilitas

Disini perushaan bekerja keras untuk menekan biaya terendah dalam membuat bangunan sehingga harganya bisa lebih rendah dibandingkan harga rumah pesaingnya serta dapat menguasai pangsa pasar yang lebih besar.

2. Stabilitas keuangan

Setiap perusahaan baik itu perusahaan yang berskala besar maupun kecil membutuhkan stabilitas keuangan. Dalam keuangan perusahaan, dapat ditinjau dari dua sisi yaitu manajemen yang pengelolaan yang tidak profesional. Dari hasil pengamatan dan wawancara dengan pimpinan PT. Trypillian Regional, diketahui bahwa manajemen pengelolaan keuangan perusahaan sudah cukup baik. Sehingga dapat dikatakan kondisi keuagan perusahaan cukup stabil. 
3. Biaya modal kerja

Setiap perusahaan baik itu perusahaan besar maupun kecil, dalam menjalankan aktifitasnya, membutuhkan modal kerja yang dapat mendukung operasional perusahaan. Modal kerja yang minim akan mempengaruhi seberapa besar produktivitas perusahaan terutama perusahaan yang bergerak dibidang pembangunan. Sebaliknya modal kerja yang memadai atau banyak akan sangat membantu perusahaan dalam menjalankan program pengembangannya. Perusahaan PT. Trypillian Regional dalam operasionalnya tidak hanya mengandalkan modal kerja milik perusahaan, yang terbilang masih minim. Pihak perusahaan dalam memodali aktivitas pembangunannya mendapatkan pinjaman modal dari mitra usaha (perbankan). Hal ini tentu saja mempengaruhi keuntungan perusahaan yang masih harus mengembalikan bunga pinjaman. Tetapi walaupun demikian perusahaan cukup terbantu dengan pinjaman tersebut.

\section{Bidang Organisasi}

Agar organisasi dapat berjalan dengan baik, maka perlu memperhatikan beberapa asas-asas organisasi seperti perumusan tujuan yang mampu berpandangan ke depan tentang apa yang menjadi tujuan dari perusahaan.

1. Kepemimpinan yag mampu dan berpandangan ke depan

Dalam organisasi pembagian kerja adalah keharusan mutlak, tanpa itu kemungkinan akan terjadi tumpang tindih menjadi amat besar. Pembagian kerja pada perusahaan PT. Trypillian Regional, dapat dapat dikatakan sudah cukup baik, karena hasil observasi penulis, sudah ada bagian-bagian pekerjaan masing-masing fungsi yang terdpat pada struktur organisasinya sudah berjalan dengan sebaik-baiknya. Kesemuanya ini karena kepemimpinan yang dilakukan dengan penuh rasa tanggung jawab terhadap kelangsungan hidup perusahaan yang dipimpinnya.

2. Kemampuan beradaptasi

Sifat yang mencerminkan oleh pimpinan perusahaan untuk dapat ternyata membuat para pegawai dan pekerja menunjukan tetap kesetiannya terhadap tanggung jawab pekerjaannya selama jamjam bekerja berlangsug. Terkadang suatu bisnis berakhir karena kegagalan. Kegeglan ini buakan karena lini lini yang tidak memiliki kekuatan, tetapi karena lini yang ada tidak dapat bekerja sama dengan baik sebagai satu tim untuk mencapai tujuan dari perusahaan. Perusahaan haruslah dapat memiliki kemampuan yang unggul dalam rangka mencapai dan mempertahankan keungulan dari para pesaingngya.

Di bawah ini akan dipaparkan beberapa kekuatan dan kelemahan yang dimiliki oleh PT. Trypillian Regional antara lain :

\section{Kekuatan}

1. Lokasi yang strategis

2. Angsuran pembayaran yang murah

3. Harga yang bersaing dari perumahan perumahan yang ada di Kota Palu

4. Kualitas bangunan yang kuat dan moderen

5. Spesifikasi bahan bangunan yang lengkap

\section{Kelemahan}

1. Belum mempunyai fasilitas umum seperti musholah dilingkungan perumahan

2. Kurangnya kegiatan promosi penjualan dimana pihak perusahaan hanya mengandalkan brosur dan informasi masyarakat yang disampaikan dari mulut-kemulut

3. Pengawasan yang kurang kontraktor sehingga banyak konsumen yang mengajukan keluhan seperti dinding tembok yang retak-retak

\section{Hasil Analisis SWOT}

Berdasarkan identifikasi variabel-variabel eksternal dan internal PT. Trypillian Regional diatas, tabel analisis eksternal faktor EFAS (Eksternal Strategic Factor Analysis Summary). Dan tabel analisis internal faktor IFAS (Internal Strategic Factor Analysis Summary) dapat dibuat. Dengan cara sebagai berikut : 
Tabel 2. Internal factor analysis (IFAS)

\begin{tabular}{|c|c|c|c|}
\hline Internal Factor Analysis & Bobot & Rating & Nilai \\
\hline \multicolumn{4}{|l|}{ Kekuatan } \\
\hline 1. Lokasi yang strategis & 0,15 & 3 & 0,45 \\
\hline 2. Angsuran pembayaran yang murah & 0,15 & 3 & 0,45 \\
\hline $\begin{array}{l}\text { 3. Harga yang bersaing dari perumahan perumahan yang ada di Kota } \\
\text { Palu }\end{array}$ & 0,15 & 3 & 0,45 \\
\hline 4. Kualitas bangunan (moderen) & 0,20 & 4 & 0,80 \\
\hline 5. Spesifikasi bahan bangunan yang lengkap & 0,10 & 2 & 0,20 \\
\hline Sub Total & \multicolumn{2}{|c|}{2,35} & \\
\hline \multicolumn{4}{|l|}{ Kelemahan } \\
\hline $\begin{array}{l}\text { 1. Belum mempunyai fasilitas umum seperti musholah dilingkungan } \\
\text { perumahan }\end{array}$ & 0,05 & 1 & 0,05 \\
\hline $\begin{array}{l}\text { 2. Kurangnya kegiatan promosi penjualan dimana pihak perusahaan } \\
\text { hanya mengandalkan brosur dan informasi masyarakat yang } \\
\text { disampaikan dari mulut-kemulut }\end{array}$ & 0,10 & 2 & 0,20 \\
\hline $\begin{array}{l}\text { 3. Pengawasan yang kurang dari kontraktor sehingga banyak konsumen } \\
\text { yang mengajukan keluhan seperti dinding tembok yang retak-retak }\end{array}$ & 0,10 & 2 & 0,20 \\
\hline Sub Total 0,25 & \multicolumn{2}{|c|}{0,45} & \\
\hline Total & .00 & & 2,80 \\
\hline
\end{tabular}

Sumber: Hasil olah data PT. Trypillian Regional

Hasil analisis pada Tabel 2, mengindikasikan bahwa strategi bersaing pada Gelatik Residence Palu menunjukan total nilai IFAS sebesar 2,80 yang diberikan dari nilai skor kekuatan sebesar 2,35 dan nilai skor kelemahan sebesar 0,45. Penentuan peringkat pun ditentukan sesuai dengan tingkat kepentingan. Pembobotan yang dianggap paling penting di berikan nilai 0,20 Nilai dari indikator kekuatan yang paling berpengaruh atau paling penting adalah kualitas bangunan yang modern hal ini disebabkan karena produk utama yang dijual oleh PT. Trypillian Regional adalah kualitas bangunan yang modern dari perumahan pada umumnya. Sementara indikator yang dianggap dalam PT. Trypilian Regional tersebut berada pada tingkat kepentingan yang rendah diberi bobot 0,05 Sedangkan dari faktor kelemahan internal yang mempengaruhi adalah strategi bersaing pada perusahaan adalah Kurangnya kegiatan promosi penjualan dan Pengawasan yang kurang dari kontraktor. Dan untuk total bobot maksimal 1,00.

Tabel 3. Eksternal Factor Analysis (EFAS)

\begin{tabular}{|c|c|c|c|}
\hline Eksternal Factor Analysis & Bobot & Rating & Nilai \\
\hline \multicolumn{4}{|l|}{ Peluang } \\
\hline $\begin{array}{l}\text { 1. Peraturan pemerintah yang mendorong pembangunan perumahan } \\
\text { nomor } 29 / 1974 \text { tentang perusahaan pembangunan nasional }\end{array}$ & 0,15 & 3 & 0,45 \\
\hline $\begin{array}{l}\text { 2. Kecenderungan masyarakat dalam memilih wilayah yang aman, dan } \\
\text { dekat dengan fasilitas umum seperti bandara dan pusat kota }\end{array}$ & 0,20 & 4 & 0,80 \\
\hline $\begin{array}{l}\text { 3. Pertumbuhan penduduk yang semakin meningkat maupun jumlah } \\
\text { pendatang yang akan membutuhkan tempat tinggal baru }\end{array}$ & 0,10 & 2 & 0,20 \\
\hline $\begin{array}{l}\text { 4. Kepercayaan masyarakat terhadap kualitas perumahan Gelatik } \\
\text { Residence untuk memberikan layanan terbaik terhadap konsumen. }\end{array}$ & 0,15 & 3 & 0,45 \\
\hline 5. Inovasi baru & 0,15 & 3 & 0,45 \\
\hline Sub Total & & & 2,35 \\
\hline \multicolumn{4}{|l|}{ Ancaman } \\
\hline 1. Munculnya berbagai perumahan/pesaing baru di kota Palu & 0,10 & 2 & 0,20 \\
\hline 2. Gaji buruh yang semakin tinggi yang akan mempengaruhi harga jual & 0,05 & 1 & 0,05 \\
\hline
\end{tabular}


perumahan menjadi mahal atau sulit terjangkau

\begin{tabular}{clrrr}
\hline 3. & Kenaikan harga material bangunan & 0,05 & 1 & 0,05 \\
\hline 4. & Perkembangan berbagai type perumahan dari para pesaing & 0,05 & 1 & 0,05 \\
\hline Sub Total 0,25 & & & 0,35 \\
\hline Total & 1.00 & 2,70 \\
\hline
\end{tabular}

Sumber : Hasil olah data PT. Trypillian Regional

Hasil analisis pada Tabel 3, mengindikasikan bahwa strategi bersaing pada Gelatik Residence Palu menunjukan total nilai EFAS sebesar 2,70 yang diberikan dari nilai skor peluang sebesar 2,35 dan nilai skor ancaman sebesar 0,35 . Penentuan peringkat pun ditentukan sesuai dengan tingkat kepentingan. Nilai dari indikator Peluang yang paling berpengaruh atau paling penting adalah kecenderungan masyarakat dalam memilih wilayah yang aman, dan dekat dengan fasilitas umum. Sedangkan dari faktor ancaman yang mempengaruhi strategi bersaing pada perusahaan adalah Munculnya berbagai perumahan/pesaing baru di kota Palu. Dan untuk total bobot maksimal 1,00. Analisis Tabel 3, menunjukan bahwa untuk factor-faktor dari peluang nilai skornya yaitu 2,35, sedangkan faktor ancaman yaitu 0,35 .selanjutnya, total skor dari masing-masing factor dapat dirinci:
1. Faktor kekuatan (strengths) $\quad: 2,35$
2. Factor kelemahan (weakness) $: 0,45$
3. Factor peluang (opportunities) $\quad: 2,35$
4. Faktor ancaman (treath) $: 0,35$

Setelah diketahui jumlah nilai bobot dan jumlah nilai skor dari masing-masing faktor yang dianalisis maka langkah selanjutnya adalah membuat matriks grand strtageic dari kekuatan dan kelemahan serta peluang dan ancaman sebagaimana yang tampak dalam Gambar 1 berikut ini.

\section{PELUANG $(2,35)$}

III

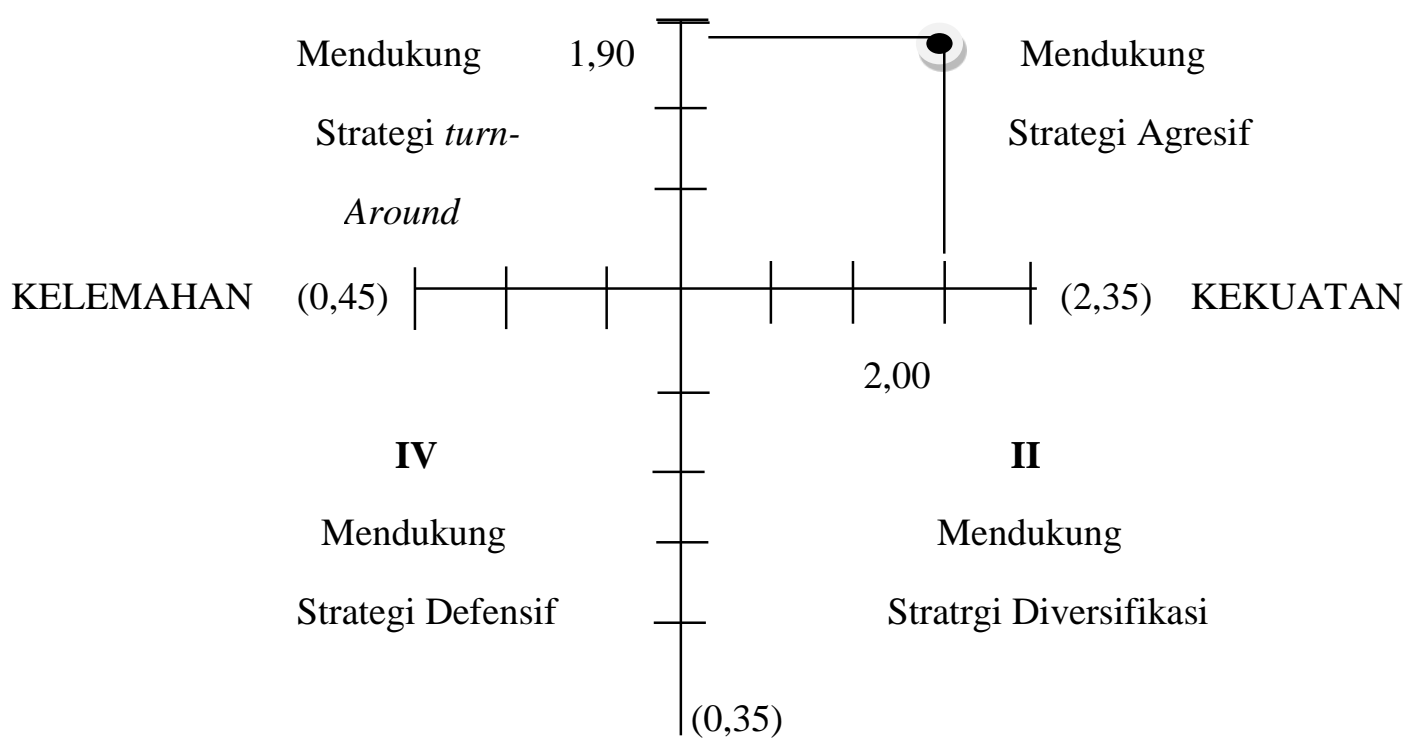

ANCAMAN

Gambar 1. Diagram Penentuan Matrik Grand Strategi

1. Kuadran I : ini merupakan situasi yang sangat menguntungkan. Usaha memiliki peluang dan kekuatan sehingga dapat memanfaatkan peluang yang ada. Strategi yang harus diterapkan dalam kondisi ini adalah mendukung kebijakan pertumbuhan yang agresif (Growth oriented strategy).

2. Kuadran II : meskipun menghadapi berbagai ancaman, usaha ini masih memiliki kekuatan dari segi internal. Strategi yang harus diterapkan adalah menggunakan kekuatan untuk memanfaatkan peluang jangka panjang dengan cara strategi diverifikasi (produk/pasar). 
3. Kuadran III : usaha menghadapi peluang pasar yang sangat besar tetapi di lain pihak, ia menghadapi beberapa kendala/kelemahan internal. Fokus strategi usaha ini adalah meminimalkan masalah-masalah internal usaha sehingga dapat merebut pasar yang lebih baik.

4. Kuadran IV : merupakan situasi yang sangat tidak menguntungkan, usaha tersebut menghadapi berbagai ancaman dan kelemahan internal.

Nilai total masing-masing faktor selain digambarkan dalam diagram SWOT juga dapat digambarkan dalam rumusan matriks SWOT sebagai berikut :

Tabel 4. Matriks SWOT Rumusan Kombinasi Strategi

\begin{tabular}{lll}
\hline & STRENGTHS $(\mathrm{S})$ & WEAKNESSES $(\mathrm{W})$ \\
& STRATEGI SO & STRATEGI WO \\
OPPORTUNITIES $(\mathrm{O})$ & $=2,35+2,35$ & $=0,45+2,35$ \\
& $=4,70$ & $=2,80$ \\
\hline & STRATEGI ST & STRATEGI WT \\
TRHEATS $(\mathrm{T})$ & $=2,35+0,35$ & $=0,45+0,35$ \\
& $=2,70$ & $=0,77$ \\
\hline
\end{tabular}

Sumber: Hasil penelitian yang diolah penulis, 2016.

Berdasarkan internal-eksternal matriks, dengan nilai total skor IFAS dan EFAS di atas kita dapat melihat beberapa kekuatan, kelemahan, peluang, dan ancaman yang di miliki oleh Gelatik Residence. Dengan memahami di mana kekuatan atau kelemahan usaha dalam persaingan, maka langkah selanjutnya yaitu menyusun strategi yang sesuai untuk menghadapi persaingan di masa depan. Dengan demikian matriks SWOT yang berisi gambaran tentang berbagai peluang dan ancaman lingkungan luar yang dihadapi oleh usaha diperhadapkan pada kekuatan dan kelemahan yang dimilikinya dengan berbagai alternatif strategi dapat dirumuskan berdasarkan SWOT. Keunggulan dengan mengunakan matriks SWOT ini adalah kita dapat dengan mudah menformulasikan strategi yang kita peroleh berdasarkan gabungan internal dan eksternal faktor. Ada 4 alternatif strategi yang dapat dipakai yaitu :

1. Strategi SO (Strenghts dan Opportunities/kekuatan dan peluang) strategi ini dimaksudkan untuk memanfaatkan semua kekuatan perusahaan dalam rangka merebut dan memanfaatkan peluang secara optimal.

2. Strategi ST (Strenghts dan Threats/kekuatan dan ancaman) ini adalah strategi dalam menggunakan kekuatan yang dimiliki perusahaan untuk mengatasi ancaman.

3. Strategi WO (Weakness dan Opportunities/kelemahan dan peluang) bagaimana memanfaatkan peulang yang ada dengan meminimalkan kelemahan perusahaan.

4. Strategi WT (Weakness dan Threats/kelemahan dan peluang) minimalisasi kelemahan untuk menghindari ancaman.

Untuk mengetahui lebih jelas aplikasi dari empat alternative strategi yang disatukan dalam SWOT dapat dilihat dalam Table 4 dan 5 diagram matriks SWOT penentuan strategi perusahaan sebagai berikut: 
Tabel 5. Matriks SWOT Penentuan Strategi Perusahaan

\begin{tabular}{|c|c|c|}
\hline EFAS & $\begin{array}{l}\text { STRENGTHS }(\mathrm{S}) \\
\text { Tentukan faktor-faktor } \\
\text { kekuatan internal }\end{array}$ & $\begin{array}{l}\text { WEAKNESSES }(\mathrm{W}) \\
\text { Tentukan faktor-faktor kekuatan } \\
\text { eksternal }\end{array}$ \\
\hline $\begin{array}{l}\text { OPPORTUNITIES }(\mathrm{O}) \\
\text { Tentukan faktor-faktor } \\
\text { peluang eksternal }\end{array}$ & $\begin{array}{l}\text { STRATEGI SO } \\
\text { Ciptakan strategi yang } \\
\text { menggunakan kekuatan untuk } \\
\text { memanfaatkan peluang }\end{array}$ & $\begin{array}{l}\text { STRATEGI WO } \\
\text { Ciptakan strategi yang } \\
\text { meminimalkan kelemahan untuk } \\
\text { memanfaatkan peluang }\end{array}$ \\
\hline $\begin{array}{l}\text { THREATS }(\mathrm{T}) \\
\text { Tentukan faktor-faktor } \\
\text { ancaman eksternal }\end{array}$ & $\begin{array}{l}\text { STRATEGI ST } \\
\text { Ciptakan strategi yang } \\
\text { menggunakan kekuatan untuk } \\
\text { mengatasi ancaman }\end{array}$ & $\begin{array}{l}\text { STRATEGI WT } \\
\text { Ciptakan strategi yang } \\
\text { memimalkan kelemahan dan } \\
\text { menghindari ancaman }\end{array}$ \\
\hline
\end{tabular}

\section{Sumber: Rangkuti (2014)}

Tabel 6. Matriks SWOT Penentuan Strategi PT. Trypillian Regional

\begin{tabular}{|c|c|c|}
\hline EFAS & $\begin{array}{l}\text { STRENGTHS (S) } \\
\text { 1. Lokasi yang strategis } \\
\text { 2. Angsuran pembayaran yang } \\
\text { murah } \\
\text { 3. Harga yang bersaing dari } \\
\text { perumahan perumahan yang ada } \\
\text { di Kota Palu } \\
\text { 4. Kualitas bangunan yang kuat dan } \\
\text { moderen } \\
\text { 5. Spesifikasi bahan bangunan yang } \\
\text { lengkap }\end{array}$ & $\begin{array}{ll}\text { WEAKNESSES }(\mathrm{W}) \\
\text { Belum mempunyai fasilitas umum } \\
\text { seperti musholah dilingkungan } \\
\text { perumahan }\end{array}$ \\
\hline $\begin{array}{l}\text { OPPORTUNITIES (O) } \\
\text { 1. Peraturan pemerintah yang } \\
\text { mendorong pembangunan } \\
\text { perumahan nomor } 29 / 1974 \text { tentang } \\
\text { perusahaan pembangunan nasional } \\
\text { 2. Kecenderungan masyarakat dalam } \\
\text { memilih wilayah yang aman, dan } \\
\text { dekat dengan fasilitas umum seperti } \\
\text { bandara dan pusat kota } \\
\text { 3. Pertumbuhan penduduk yang } \\
\text { semakin meningkat maupun jumlah } \\
\text { pendatang yang akan membutuhkan } \\
\text { tempat tinggal baru } \\
\text { 4. Kepercayaan masyarakat terhadap } \\
\text { kualitas perumahan Gelatik } \\
\text { Residence untuk memberikan } \\
\text { layanan terbaik terhadap konsumen. } \\
\text { 5. Inovasi baru }\end{array}$ & $\begin{array}{l}\text { STRATEGI SO } \\
\text { 1. Dengan tempat atau lokasi yang } \\
\text { strategis maka masyarakat dapat } \\
\text { memilih wilayah yang aman untuk di } \\
\text { tinggali dan Gelatik residence sendiri } \\
\text { dekat dengan fasilitas umum seperti } \\
\text { bandara dan pusat kota maka akan } \\
\text { mempermudah konsumen dalam } \\
\text { melakukan aktivitas. } \\
\text { 2. Meningkatkan kembali kulitas, baik } \\
\text { kualitas dalam pelayanan maupun } \\
\text { kualitas bangunan agar kepercayaan } \\
\text { konsumen terhadap perumahan yang } \\
\text { dibuat Gelatik residence tetap baik } \\
\text { dimata masyarakat. }\end{array}$ & $\begin{array}{l}\text { STRATEGI WO } \\
\text { 1. Meningkatkan kembali Membuat } \\
\text { fasilitas umum seperti musholah di } \\
\text { likungan terdekat perumahan } \\
\text { 2. Pengawasan terhadap hasil kerja dari } \\
\text { kontraktor maupun buruh agar } \\
\text { mengurangi keluhan-keluhan dari } \\
\text { konsumen terkait masalah internal } \\
\text { perumahan. }\end{array}$ \\
\hline $\begin{array}{l}\text { THREATS }(\mathrm{T}) \\
\text { 1. Munculnya berbagai } \\
\text { perumahan/pesaing baru di kota Palu } \\
\text { 2. Gaji buruh yang semakin tinggi yang } \\
\text { akan mempengaruhi harga jual } \\
\text { perumahan menjadi mahal atau sulit } \\
\text { terjangkau } \\
\text { 3. Kenaikan harga material bangunan } \\
\text { 4. Perkembangan berbagai type } \\
\text { perumahan dari para pesaing }\end{array}$ & $\begin{array}{l}\text { STRATEGI ST } \\
\text { 1. Menciptakan perumahan yang } \\
\text { berkualitas dengan menggunakan } \\
\text { bahan-bahan yang baik dan tenaga } \\
\text { kerja yang handal dalam bidangnya }\end{array}$ & $\begin{array}{l}\text { STRATEGI WT } \\
\text { 1. Gelatik resindence harus lah gencar } \\
\text { dalam melakukan promosi } \\
\text { 2. Melakukan kegiatan promosi yang } \\
\text { intensif dimedia cetak, } \\
\text { elektronik/online, seperti Koran, } \\
\text { majalah perumahan, maupun internet, } \\
\text { agar masyarakat dapat mengetahui } \\
\text { tentang adanya perumahan Gelatik } \\
\text { Residence. }\end{array}$ \\
\hline
\end{tabular}

Sumber Data: Hasil penelitian yang diolah penulis 


\section{Strategi Berdasarkan Hasil Analisis SWOT}

Berdasarkan Gambar 1 hasil dari evaluasi dan terpetakan pada kuadran SO (Strenghts dan Opportunities/kekuatan dan peluang) strategi ini dimaksudkan untuk memanfaatkan semua kekuatan perusahaan dalam rangka merebut dan memanfaatkan peluang secara optimal. Strategi SO yang telah disebutkan pada Table 6 akan melakukan usaha memiliki peluang dan kekuatan sehingga dapat memanfaatkan peluang yang ada dengan cara Srategi Agresif (Growth oriented strategy) dengan program strategi sebagai berikut :

1. Meningkatkan volume penjualan melalui peningkatan target penjualan dan perluasan pasar sasaran serta meningkatkan pengawasan terhadap hasil kerja kontraktor di lapangan dengan melakukan pengecekan berkala.

2. Meningkatkan pangsa pasar dengan membidik pasar karyawan dan wiraswasta dengan memanfaatkan peluang target pasar yang besar, tingkat bunga KPR yang rendah dan loyalitas pemasok.

3. Melakukan kegiatan promosi yang intensif dan efektif di media cetak maupun media elektronik/online, contohnya koran, majalah perumahan, TV, maupun internet.

4. Menciptakan produk yang berkualitas, tahan lama dan mengikuti tren dengan menggunakan bahan baku yang baik dan tenaga kerja yang ahli.

Berdasarkan empat alternatif strategi di atas, bauran pemasaran yang harus ditingkatkan adalah strategi tempat, strategi harga, strategi promosi, dan strategi produk. Prioritas utama adalah strategi tempat karena lokasi Perumahan Gelatik Residence yang strategis, maka dengan banyaknya akses menuju perumahan dapat memberikan kemudahan bagi konsumen untuk menuju ke lokasi, sehingga dapat menarik minat konsumen. Strategi harga dilakukan dengan memberikan kemudahan dalam pembayaran, yaitu dapat dilakukan dengan cara, cash bertahap, dan dengan kredit (KPR). Strategi promosi dengan melakukannya secara intensif dan efektif di media cetak maupun media elektronik/online. Sedangkan strategi produk dilakukan dengan pengembangan produk yang berkualitas, tahan lama dan mengikuti tren dengan menggunakan bahan baku yang baik dan tenaga kerja yang ahli.

\section{KESIMPULAN DAN SARAN}

\section{Kesimpulan}

Berdasarkan hasil pembahasan yang dikemukakan, maka dapat ditarik suatu kesimpulan :

1. Dari faktor internal, kekuatan Perumahan Gelatik Residence adalah lokasi yang strategis, angsuran pembayaran yang lumayan murah, harga yang bersaing sesuai dengan kelasnya, model rumah yang moderen, spesifikasi bahan bangunan yang lengkap.

2. Dari faktor eksternal, peluang Perumahan Gelatik Residence adalah peraturan pemerintah yang mendorong pembangunan perumahan, daya beli masyarakat/tingginya keinginan masyarakat untuk memiliki tempat tinggal, pertumbuhan penduduk yang semakin meningkat, target market yang besar, inovasi baru.

3. Dari hasil pembahasan yang dikemukakan, maka dapat ditarik suatu kesimpulan bahwa berdasarkan hasil dari analisis SWOT, menunjukan bahwa internal strategic factor analysis summary (IFAS) kekuatan dan kelemahan perusahaan Perumahan Gelatik Residence dengan total skor dan external strategic factor analysis summary (EFAS) peluang dan ancaman sebesar dari hasil tersebut sebaiknya perusahaan menggunakan strategi SO dengan memanfaatkan semua kekuatan perusahaan dalam rangka merebut dan memanfaatkan peluang yang ada secara optimal.

\section{Saran}

Berdasarkan pada analisis dan kesimpulan yang berkaitan dengan penelitian ini, maka saransaran yang dapat diajukan adalah :

1. Sebaiknya perusahaan membuat laporan setiap periode tentang kekuatan, kelemahan, peluang serta ancaman yang harus dimonitor dan dimengerti jika usaha itu mencapai tujuannya, sehingga lebih cepat mengatasi perkembangan yang terjadi terutama dalam persaingan pasar khususnya di kota Palu.

2. Sebagai aplikasi terhadap peningkatan dan mempertahankan posisi perusahaan terhadap lingkungan para pesaing, maka manajer atau pimpinan perusahaan yang bertanggung jawab 
Djuma, T DG.

langsung terhadap peningkatan perusahaan sudah harus memikirkan tentang pemanfaatan peluang yang ada, terutama peluang dalam berinovasi dalam membangun perumaan dengan model terbaru agar dapat mengusai pasar.

\section{REFERENSI}

Fahmi, I. (2014). Manajemen Strategis dan Aplikasi, edisi 2. Bandung: Alfabeta

Kotler, Philip \& Keller, K. L. (2013). Manajemen Pemasaran (13th ed.2). Jakarta: Erlangga.

Kotler, P. \& Amstrong, G. (2008). Prinsip-prinsip Pemasaran Edisi 1. Jakarta: Erlangga.

Porter, M. E. (2007). Strategi Bersaing: Teknik Menganalisis Industri dan Pesaing. Terjemahan Agus

Maulana. Jakarta: Erlangga

Rangkuti, F. (2014). Analisis SWOT: Teknik Membedah Kasus Bisnis, Edisi 19. Jakarta: CV. Prima Grafika. 